\title{
References
}

Appel, P. W. U. 1974: On an unmetamorphosed iron-formation in the early Precambrian of South-West Greenland. Miner. Deposita 9, 75-82.

Appel, P. W. U. \& Secher, K. 1984: On a gold mineralization in the Precambrian Tartoq Group, SouthWest Greenland. J. geol. Soc. Lond. 141, 273-278.

Berthelsen, A. \& Henriksen, N. 1975: Geological map of Greenland 1:100 000 Ivigtut 61 V. 1 Syd. Copenhagen: Grønlands geol. Unders. (also Meddr Grønland 186, 1) 169 pp.

Fripp, R. E. P. 1976: Stratabound gold deposits in Archean banded iron-formation, Rhodesia. Econ. Geol. 71, 58-75.

Higgins, A. K. 1968: The Tartoq Group on Nuna qaqertoq and in the Iterdlak area, South-West Greenland. Rapp. Grønlands geol. Unders. 17, 17 pp.

Higgins, A. K. 1970: The stratigraphy and structure of the Ketilidian rocks of Midternæs, South-West Greenland. Bull. Grønlands geol. Unders. 87 (also Meddr Grønland 189, 2) 96 pp.

Higgins, A. K. \& Bondesen, E. 1966: Supracrustals of pre-Ketilidian age (the Tartoq Group) and their relationships with Ketilidian supracrustals in the Ivigtut region, South-West Greenland. Rapp. Grønlands geol. Unders. 8, $21 \mathrm{pp}$.

Kanasevich, E. R. \& Slawson, W. F. 1964: Precision intercomparisons of lead isotope ratios: Ivigtut, Greenland. Geochim. cosmochim. Acta 28, 541-549.

Larsen, O. 1971: Preliminary report on K/Ar dating in the southeastern part of the Ivigtut region. Rapp. Grønlands geol. Unders. 35, 49-52.

Micheelsen, H. 1955: Rapport over det geologiske feltarbejde i Sermiligârssuk i sommeren 1955. Unpubl. intern. GGU rep., 14 pp.

Ulrych, T. J. 1964: The anomalous nature of Ivigtut lead. Geochim. cosmochim. Acta 28, 1389-1396.

Weidmann, M. 1964: Géologie de la région située entre Tigssaluk fjord et Sermiligârssuk fjord (partie médiane), SW-Groenland. Bull. Grønlands geol. Unders. 40 (also Meddr Grønland 169, 1), 146 pp.

Windley, B. F., Henriksen, N., Higgins, A. K., Bondesen, E. \& Jensen, S. B. 1966: Some border relations between supracrustal and infracrustal rocks in South-West Greenland. Rapp. Grønlands geol. Unders. 9, 43 pp.

\section{Geological and radiometric mapping of the Motzfeldt Centre of the Igaliko Complex, South Greenland}

\author{
Tapani Tukiainen, Colin Bradshaw and C. Henry Emeleus
}

The geological and radiometric mapping of the Motzfeldt Centre was commenced in 1982 as part of the extended Syduran project under the Ministry of Energy's Research Programmes of 1981 and 1982 (Armour-Brown et al., 1983). The purpose of the study was to make a detailed geological and radiometric map of the centre with a view to provide a reliable reference framework for the evaluation of the economic mineral potential of the centre where an extensive $\mathrm{Th}-\mathrm{U}-\mathrm{Zr}-\mathrm{Nb}-\mathrm{REE}$ mineralisation was discovered by the reconnaissance surveys of the Syduran project, which was partly financed by the European 
Economic Communities during the period 1st Dec. 1979 - 1st Dec. 1980 under article 70 (Armour-Brown et al., 1982, 1983). Apart from a short visit by Agnete Steenfelt, who carried out a detailed rock-sampling programme of a section in the north-east part of the centre, no field work was done during the 1983 season. The geological mapping of the centre is planned to be finished during the 1984 season. The airborne gamma-spectrometric and field mapping data of the 1982 season have been processed and compiled, so we are able to summarise the most important results.

\section{Geology}

The Motzfeldt area with steep-sided glacially dissected valleys provides a virtually threedimensional, c. $1500 \mathrm{~m}$ high vertical exposure across a major multiphase, high-level alkaline intrusion where an extensive hydrothermal alteration and mineralisation took place in the roof zone as a result of the upward migration of a highly mobile volatile phase, rich in incompatible elements.

The revised geology of the Motzfeldt Centre is shown in fig. 34 which also gives a new rock-unit nomenclature. The new nomenclature was developed because of its flexibility in allowing previously undescribed syenite units, found during Syduran mapping and in the future mapping studies, to be included without confusing changes in the 'SM' notation of Emeleus \& Harry (1970). The new nomenclature has been established on the basis of the present mapping. The extension of the syenite formations to the southern and western parts of the centre are still tentative as they are based on the available fragmentary field evidence and results of the gamma-spectrometric survey.

The Motzfeldt Centre developed through two major phases of igneous activity. The syenite units of the early igneous phase, the Geologfjeld Formation, originally comprised a number of separate syenite stocks which are now truncated by the syenite units of the main igneous phase, the Motzfeldt Ring Series. The wide extent of the Geologfjeld Formation Syenite in the north-east part of the centre indicates that at least some of these early syenite bodies may have been considerable.

The Motzfeldt Ring Series is made up of concentric steep-sided intrusions whose marginal contacts dip outwards. The syenite intrusions young inwards. The obvious intrusion mechanism, as already proposed by Emeleus \& Harry (1970), was the successive emplacement of syenite guided by a combination of ring fractures and block subsidence.

The main igneous phase commenced with the emplacement of the Motzfeldt Sø Formation which now occupies the outer zone of the Motzfeldt Ring Series. This formation is divided into three concentric units, namely: the outermost marginal arfvedsonite syenite, heterogeneous altered nepheline syenite and the innermost fresh nepheline syenite. The Motzfeldt S $\emptyset$ Formation hosts extensive radioactive mineralisation and the metasomatic alteration described below. The boundary of the alteration is in places conspicuously sharp, but no evidence of the syenite units as separate intrusions was found. It appears more probable, therefore, that the Motzfeldt S $\varnothing$ Formation is a single major intrusion whose margins were extensively modified by late magmatic processes resulting in the altered nepheline syenite unit.

The Flinks Dal Formation is made up of at least three separate intrusions, emplaced in the following order: porphyritic nepheline microsyenite, foyaite and a coarse-grained nepheline syenite. The foyaite occurs as a number of narrow, near vertical sheet-like intrusions with a 


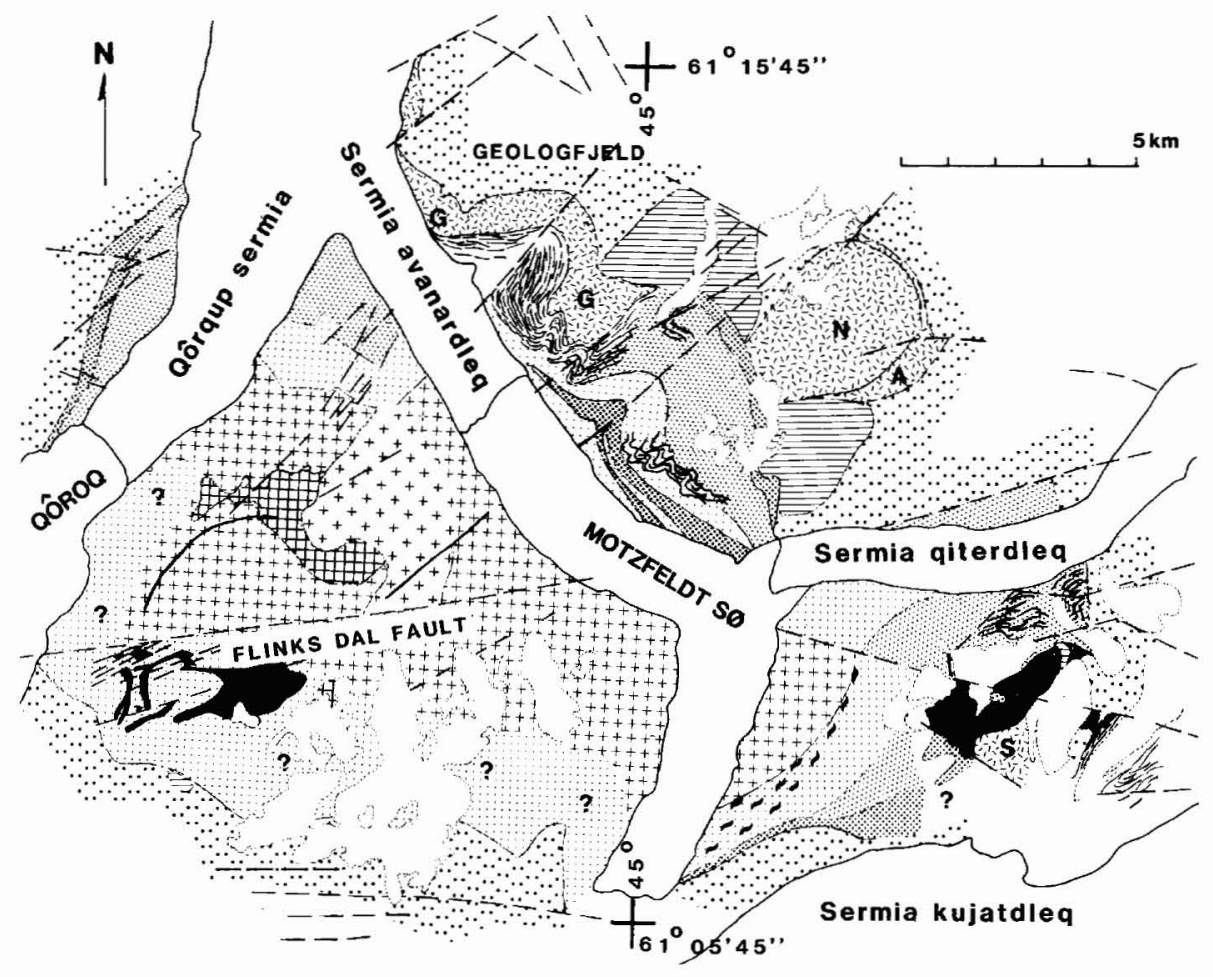

LATE SHEETED INTRUSIONS

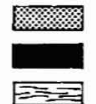

Fayalite alkali syenite

Peralkaline microsyenite suite

世曹 Trachytic and/or phonolitic ratt

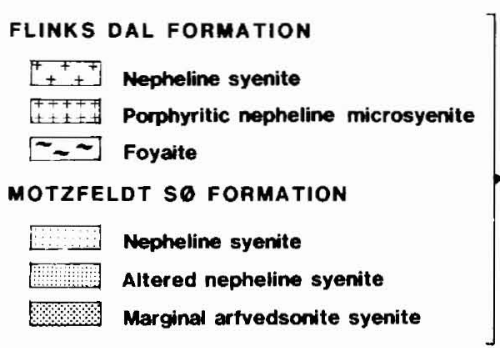

GEOLOGFJELD FORMATION

Geologfjeld arfvedsonite syenite

Alkali syenite

[N. Nepheline syenite

Sodalite syenite

ERIKSFJORD FORMATION

Sandstone and quartzite with basaltic flows

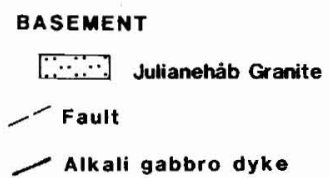

Fig. 34. Revised geology of the Motzfeldt Centre.

range of widths from about 1 to $20 \mathrm{~m}$, cutting both the Motzfeldt $\$ \varnothing$ Formation nepheline syenite and the Flinks Dal Formation porphyritic nepheline microsyenite. The relative age of the coarse-grained nepheline syenite and foyaite remains uncertain because of the lack of definite field evidence. 


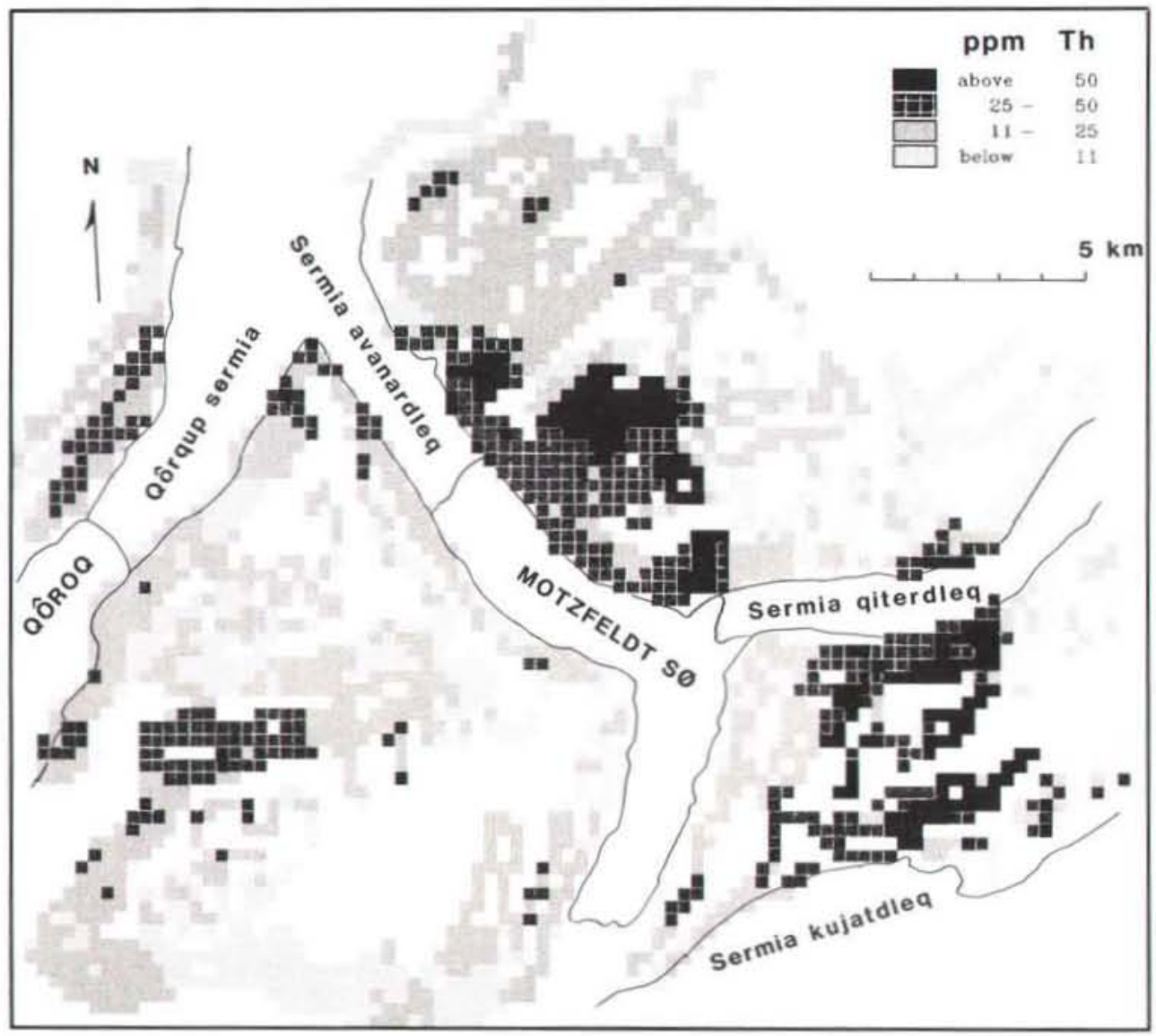

Fig. 35. Thorium airborne radiometric map of the Motzfeldt Centre. The grid size is $300 \times 300 \mathrm{~m}$, the average of the measurements in each grid is shown.

The syenite units of the late sheeted intrusions are both mineralogically and texturally highly variable, and their relations with each other and the syenite formations of the Motzfeldt Ring Series are not understood. They are, however, definitely younger than the Motzfeldt Sø Formation. There is some field evidence to suggest that at least the peralkaline microsyenite suite could be genetically related to the Motzfeldt Sø Formation because (a) the peralkaline microsyenite sheets were not found to intrude the Flinks Dal Formation, (b) the microsyenite sheets are almost exclusively found within the Motzfeldt Sø Formation increasing in width and number upwards in this formation, and (c) both the Motzfeldt Sø Formation and peralkaline microsyenite are enriched in the incompatible elements.

The syenite units of the centre were affected by two major sets of vertical or nearly vertical faults, one striking NE-SW (older), and another E-W (younger). The most dramatic dislocations in the centre took place along the E-W striking faults. The most spectacular of these faults, the Flinks Dal Fault, traverses the whole Motzfeldt Centre with a horizontal sinistral component of about $6 \mathrm{~km}$. The E-W striking faults also have a distinct 
vertical component; the biggest observed vertical displacement along one of these faults is $180 \mathrm{~m}$.

\section{Distribution of uranium and thorium}

The airborne gamma-spectrometric survey has outlined the extent of the radioactive mineralisation, showing that it is intimately associated with the rock units of the Motzfeldt $\mathrm{S} \varnothing$ Formation and the late sheeted intrusions within it (fig. 35). The overall picture of K, eU and Th distribution on the airborne radiometric maps of the centre is essentially similar.

The Motzfeldt Sø Formation together with the peralkaline microsyenite suite has the highest content of eU and Th in the Motzfeldt Centre (fig. 35). It contains numerous zones of very high $\mathrm{eU}$ and $\mathrm{Th}$. The areas with $9 \mathrm{ppm}$ eU and $15 \mathrm{ppm}$ Th coincide well with the mapped outlines of the Motzfeldt Sø Formation.

The ground underlain by the Flinks Dal and Geologfjeld Formations has a relatively low level of eU and Th without prominent anomalies. Distinct aerial variations do occur but whether these reflect lithological variations is not known.

The Eriksfjord Formation is characterised by a low and relatively uniform content of eU and $T h$. Even in the areas where this formation caps the radioactive Motzfeldt Sø Formation it appears to have remained virtually unaffected by the radioactive mineralisation.

The patterns of distribution of the radioactive element in the basement granite have no obvious correlation with the distribution of the various rock types as indicated on the 1:100 000 scale geological map (Allaart, 1970). There are two areas, one south-west of the centre and another at Geologfjeld, which have a strikingly high background content of radioactive elements.

\section{$T h-U-Z r-N b-R E E$ mineralisation}

The metasomatic alteration and mineralisation are spatially related and increase in intensity towards the uppermost parts of the Motzfeldt $\$ \emptyset$ Formation, being most intense where the roof zone of the intrusion is preserved. The alteration is essentially due to the breakdown of mafic minerals and the formation of iron oxides and micas and to albitisation. The altered rocks are also notably enriched in fluorine as manifested by the abundance of fluorite. The bulk of the radioactive elements are contained in two groups of minerals, namely zirconiumbearing minerals and pyrochlore.

The predominance of thorium over uranium in the Motzfeldt S $\emptyset$ Formation is due to the high content of the zirconium minerals with a high thorium content. The study of thin sections and preliminary microprobe assays suggest that the zirconium minerals in the altered rocks belong to the zircon group, ranging from a typical fresh zircon to probably hydrous metamict phases rich in thorium. The fresh rocks of the peralkaline microsyenite suite are also rich in zirconium due to the abundance of eudialyte.

Pyrochlore is a common accessory in the altered rocks, but locally it is found in considerable amounts occuring as disseminated grains and small veinlets. It is characteristic of the pyrochlore in the Motzfeldt Centre that it has a high content of uranium and LREE (Table 3 ). The analyses of pyrochlore-bearing rocks, especially those from the altered nepheline syenite, indicate an interestingly high tantalum content of up to $0.6 \%$ Ta (analysed by the neutron activation method). 
Table 3. Microprobe analysis (90 points analysed) of pyrochlore grains from the altered microsyenite south of Geologfjeld

\begin{tabular}{lcccc}
\hline Element & Mean $\%$ & Max $\%$ & Min $\%$ & Std. dev. \\
\hline $\mathrm{Na}_{2} \mathrm{O}$ & 1.56 & 7.08 & 0.00 & 2.13 \\
$\mathrm{SiO}_{2}$ & 2.58 & 9.41 & 0.13 & 2.77 \\
$\mathrm{CaO}$ & 4.71 & 9.54 & 0.11 & 2.37 \\
$\mathrm{TiO}_{2}$ & 3.97 & 5.37 & 1.49 & 0.87 \\
$\mathrm{ZrO}_{2}$ & 0.86 & 8.48 & 0.00 & 0.93 \\
$\mathrm{Nb}_{2} \mathrm{O}_{5}$ & 48.43 & 63.00 & 32.01 & 5.92 \\
$\mathrm{Ta}_{2} \mathrm{O}_{5}$ & 1.79 & 3.69 & 0.00 & 0.52 \\
$\mathrm{Ce}_{2} \mathrm{O}_{3}$ & 6.17 & 8.56 & 1.88 & 1.60 \\
$\mathrm{La}_{2} \mathrm{O}_{3}$ & 3.96 & 6.13 & 0.62 & 1.21 \\
$\mathrm{Y}_{2} \mathrm{O}$ & 0.22 & 0.32 & 0.00 & 0.20 \\
$\mathrm{ThO}_{2}$ & 0.24 & 1.02 & 0.00 & 0.19 \\
$\mathrm{UO}_{2}$ & 6.48 & 8.91 & 2.95 & 0.97 \\
\hline
\end{tabular}

\section{Conclusions}

The Motzfeldt Centre appears to be a classic example of a large multiphase alkaline intrusion where an extensive hydrothermal alteration and associated mineralisation, due to the upward migration of a highly mobile alkaline volatile phase rich in incompatible elements, occurred in the roof zone of the intrusion.

The extent and intensity of the enrichment of $\mathrm{Th}, \mathrm{U}, \mathrm{Zr}, \mathrm{Nb}$ and REE makes the Motzfeldt Centre an interesting counterpart to the celebrated Ilímaussaq Intrusion in the Gardar province of South Greenland. The excellent exposure makes the centre a rewarding target for both economic, geological, and other scientific studies.

\section{References}

Allaart, J. H. 1970: Geological map of Greenland 1:100 000, Narssarssuaq, 61 V.3 Syd. Copenhagen: Geol. Surv. Greenland.

Armour-Brown, A., Tukiainen, T. \& Wallin, B. 1982: The South Greenland Uranium Exploration Programme. Final Report. Unpubl. intern GGU rep., 92 pp.

Armour-Brown, A., Tukiainen, T., Wallin, B., Bradshaw, C. \& Emeleus, C. H. 1983: Uranium exploration in South Greenland. Rapp. Grønlands geol. Unders. 115, 68-75.

Emeleus, C. H. \& Harry, W. T. 1970: The Igaliko nepheline syenite complex. General description. Bull. Grønlands geol. Unders. 85 (also Meddr Grønland 186,3) 116 pp.

C.B. \& C.H.E., Department of Geological Sciences, Sciences Laboratories, University of Durham, $U . K$. 